\title{
Penghentian obat anti tuberkulosis pada meningitis tuberkulosis
}

\author{
Sujie Pratiwi ${ }^{1}$, Mochamad Iskandarsyah Agung Ramadhan², \\ Merry Kartika ${ }^{3}$, Yudhisman Imran ${ }^{4,5}$
}

\begin{abstract}
ABSTRAK
\section{LATAR BELAKANG}

Penghentian Obat Anti Tuberkulosis (OAT) pada dugaan Meningitis Tuberkulosa (METB) dapat dilakukan dengan penilaian gejala klinis, dan Computerized Tomography (CT) Scan kepala dengan kontras.

\section{DESKRIPSI KASUS}

Pasien laki-laki, usia 36 tahun, dibawa ke instalasi gawat darurat (IGD) RS Hermina Daan Mogot dengan keluhan penurunan kesadaran bertahap sejak 1 hari yang lalu. Pasien mengeluh nyeri kepala yang memberat dalam 3 bulan, demam naik turun sejak 1 bulan. Pasien memiliki riwayat kontak serumah dengan penderita Tuberkulosis (TB). Pada pemeriksaan neurologi didapatkan, Glasgow Coma Scale (GCS) E3M5V2, tanda rangsangan meningeal (+) dan test HIV (-). CT Scan kepala dengan kontras didapatkan penyengatan kontras minimal di daerah sisterna silvii bilateral dan sisterna basalis dan kronik iskemik serebral infark pada frontoparietal kanan. Pasien mendapatkan tata laksana antiedema dan OAT kategori I. Setelah terdapat perbaikan klinis berupa perbaikan kesadaran menjadi compos mentis dan derajat nyeri kepala berkurang, pasien pulang dengan tata laksana antiedema, OAT dan antiplatelet. Saat rawat jalan pasien masih mengeluhkan nyeri kepala, dilakukan pemeriksaan CT Scan kepala, masih terdapat penyengatan kontras hingga bulan ke-12 dan ke-15. Pada bulan ke-18 pasien sudah tidak mengeluhkan nyeri kepala dan tidak terdapat penyengatan kontras pada CT scan kepala sehingga OAT dapat dihentikan.
\end{abstract}

\section{KESIMPULAN}

Pemberian OAT bervariasi pada setiap individu. Perpanjangan dan penghentian terapi dipertimbangan berdasarkan kondisi pasien dan dapat didukung dengan pemeriksaan penunjang seperti CT Scan kepala.

Kata kunci: obat anti tuberkulosis, CT Scan dengan kontras, meningitis tuberkulosis
${ }^{1}$ Fakultas Kedokteran Universitas Syiah Kuala, Banda Aceh, Indonesia

${ }^{2}$ Fakultas Kedokteran Universitas Indonesia, Jakarta, Indonesia

${ }^{3}$ RSUD Dr. H. Chasan Boesoirie, Ternate, Maluku Utara, Indonesia

${ }^{4}$ RS Hermina Daan Mogot, Jakarta, Indonesia

${ }^{5}$ Departemen Ilmu Penyakit Saraf, Fakultas Kedokteran Universitas Trisakti, Jakarta, Indonesia

\section{Korespondensi:}

Sujie Pratiwi

Jalan Mardani III No.28 RT11/

RW10 Cempaka Putih, Jakarta

Pusat, DKI Jakarta 10520

Phone: +6285274455678

Email: sujiepratiwi@yahoo.com

J Biomedika Kesehat 2020;3(1):28-32 DOI: $10.18051 /$ JBiomedKes.2020. v3.28-32

pISSN: 2621-539X / eISSN: 2621-5470

Artikel akses terbuka (open access) ini didistribusikan di bawah lisensi Creative Commons Attribution 4.0 International (CC-BY 4.0) 


\section{ABSTRACT}

\section{Termination of anti-tuberculosis drugs in tuberculosis meningitis}

\section{BACKGROUND}

Termination of anti-tuberculosis drugs (ATD) in patient suspected with Tuberculous Meningitis (TBM) can evaluated by clinical manifestations and contrast-enhanced Computerized Tomography (CT) Scan of the head.

\section{CASE DESCRIPTION}

A 36-year old man taken to emergency unit of Daan Mogot Hermina Hospital with progressing loss of consciousness one day before admission. He complained worsening headache within three months and intermittent fever within a month. Contact tracing was significant for a contact with household member infected with tuberculosis. Neurological examinations revealed Glasgow Coma Scale (GCS) of E3M5V2 and positive meningeal sign and HIV test (-). Head CT-Scan with contrast detected minimal enhancement within basal cistern and bilateral Sylvian cistern along with ischemic cerebral infarction within right frontoparietal area. Antiedema therapy and ATD were given. He was discharged with antiedema, ATD and antiplatelet being continued after clinical improvement awareness has become compos mentis and the level of headache is reduced. However he still complained recurrent headache during follow-up visit. Contrasted CT-Scan done in 12th and 15th month follow-up showed persisting contrast enhancement. ATD regimen was terminated as no enhancement found on 18th month follow-up.

\section{CONCLUSION}

Durations of ATD regimen given in patients with TBM may be individual-tailored. Prolongation or termination of therapy should be judged by clinical course and may be supported with other evaluation including head CT-Scan with contrast.

Keywords: anti-tuberculosis drugs, head CT Scan with contras, meningitis tuberculosis

\section{PENDAHULUAN}

Meningitis tuberkulosis (METB) adalah manifestasi klinis tuberkulosis yang paling berat dengan angka kejadian sekitar $10 \%$ dari semua kasus tuberkulosis. ${ }^{(1)}$ Setiap tahunnya terdapat sekitar 100.000 kasus baru METB di negara berkembang. ${ }^{(1,2)}$ Di Indonesia dilaporkan jumlah semua kasus baru TB sebanyak 420.994 kasus pada tahun 2017, dengan laki-laki 1.4 kali lebih banyak dibandingkan perempuan. ${ }^{(3)}$ Berdasarkan rekomendasi WHO, pengobatan jangka panjang METB menggunakan rejimen standar (isoniazid, rifampisin, pirazinamid dan etambutol) dengan durasi 9 hingga 12 bulan ditambah dengan pemberian kortikosteroid yang terbukti mampu menurunkan angka kematian akibat METB. ${ }^{(4-}$ 8) Perpanjangan durasi pengobatan antimikroba pada kasus METB dikaitkan dengan berbagai faktor. Penghentian Obat Anti Tuberkulosis (OAT) pada dugaan Meningitis Tuberkulosa (METB) diharapkan dapat dilakukan dengan penilaian gejala klinis, dan Computerized Tomography (CT) Scan atau Magnetic Resonance Imaging (MRI) kepala dengan kontras sebagai modalitas terapi. $(9,10)$

\section{DESKRIPSI KASUS}

Pasien laki-laki, usia 36 tahun, dibawa ke instalasi gawat darurat (IGD) RS Hermina Daan
Mogot dengan keluhan penurunan kesadaran bertahap sejak 1 hari yang lalu. Pasien mengeluh nyeri kepala yang memberat dalam 3 bulan, demam naik turun sejak 1 bulan. Pasien memiliki riwayat kontak serumah dengan penderita TB. Pada pemeriksaan neurologi didapatkan, Glasgow Coma Scale (GCS) E3M5V2, tanda rangsangan meningeal (+) dan Tes HIV (-). CT Scan kepala dengan kontras didapatkan penyengatan kontras minimal di daerah sisterna silvii bilateral dan sisterna basalis dan kronik iskemik serebral infark pada frontoparietal kanan. Pasien mendapatkan tata laksana antiedema Dexametason $0.6 \mathrm{mg} /$ $\mathrm{kgBB} / \mathrm{hari}$, OAT kategori I yang terdiri dari Isoniazid $10 \mathrm{mg} / \mathrm{kgBB} / \mathrm{hari}$, Rimfampisin 15$20 \mathrm{mg} / \mathrm{kgBB} / \mathrm{hari}$, Ethambutol $15-25 \mathrm{mg} / \mathrm{kgBB} /$ hari, dan Pirazinamid $35 \mathrm{mg} / \mathrm{kgBB} /$ hari serta antiplatelet aspilet $80 \mathrm{mg} /$ hari. Setelah perbaikan klinis, kesadaran compos mentis dan derajat nyeri kepala berkurang, pasien pulang dengan tata laksana antiedema, OAT dan antiplatelet. Saat rawat jalan pasien masih mengeluhkan nyeri kepala, dilakukan pemeriksaan CT Scan kepala, masih terdapat penyengatan kontras hingga bulan ke-12 dan ke-15. Pada bulan ke-18 pasien sudah tidak mengeluhkan nyeri kepala dan tidak terdapat penyengatan kontras pada CT scan kepala sehingga OAT dapat dihentikan. 
Gambar 1. CT scan pre-kontras dan post kontras bulan pertama pengobatan
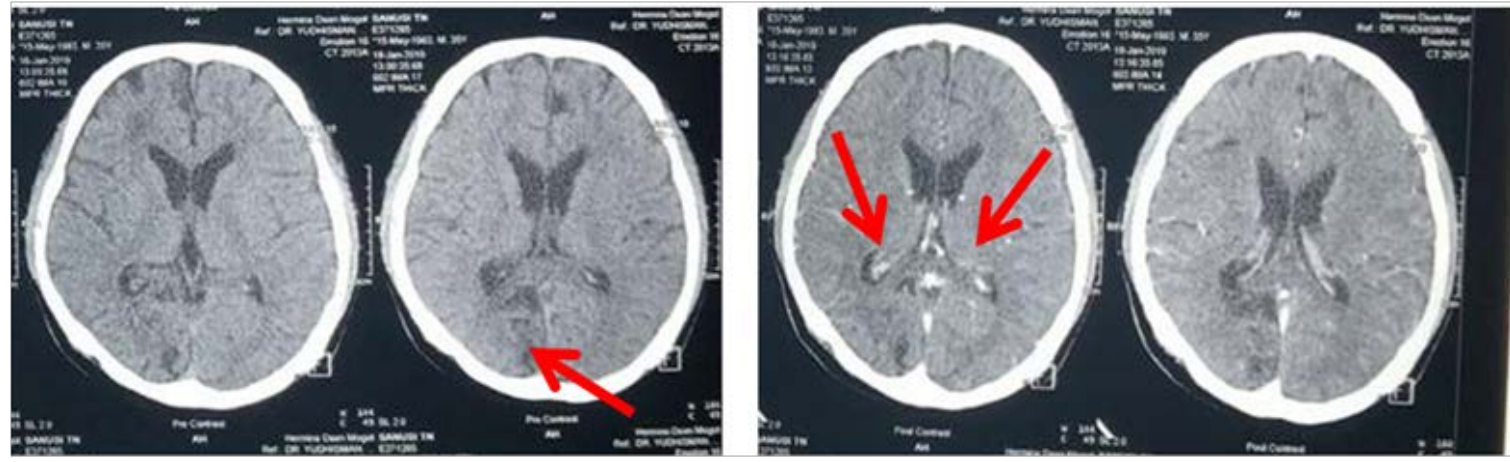

Interpretasi: Penyengatan kontras di daerah sisterna silvii bilateral dan sisterna basalis dan kronik iskemik serebral infark pada frontoparietal kanan (tanda panah)

Gambar 2. CT scan pre-kontras dan post kontras pada bulan ke-12 pengobatan
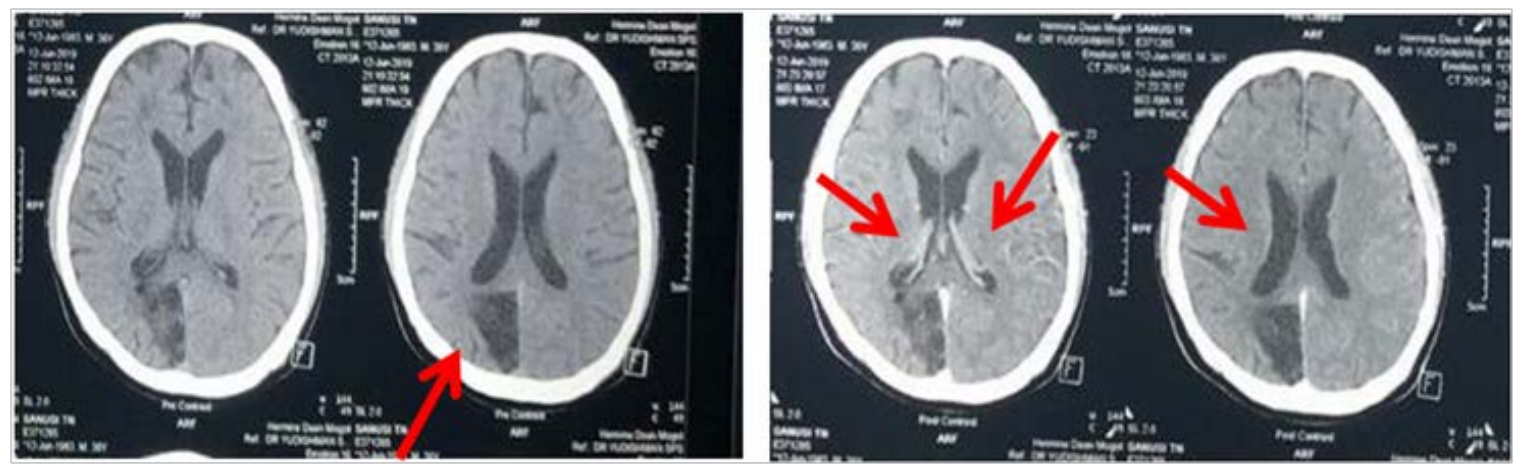

Interpretasi: Penyengatan kontras minimal di daerah sisterna silvii bilateral dan sisterna basalis dan kronik iskemik serebral infark pada frontoparietal kanan (tanda panah)

\section{Gambar 3. CT scan pre-kontras dan post kontras pada bulan ke-18 pengobatan}
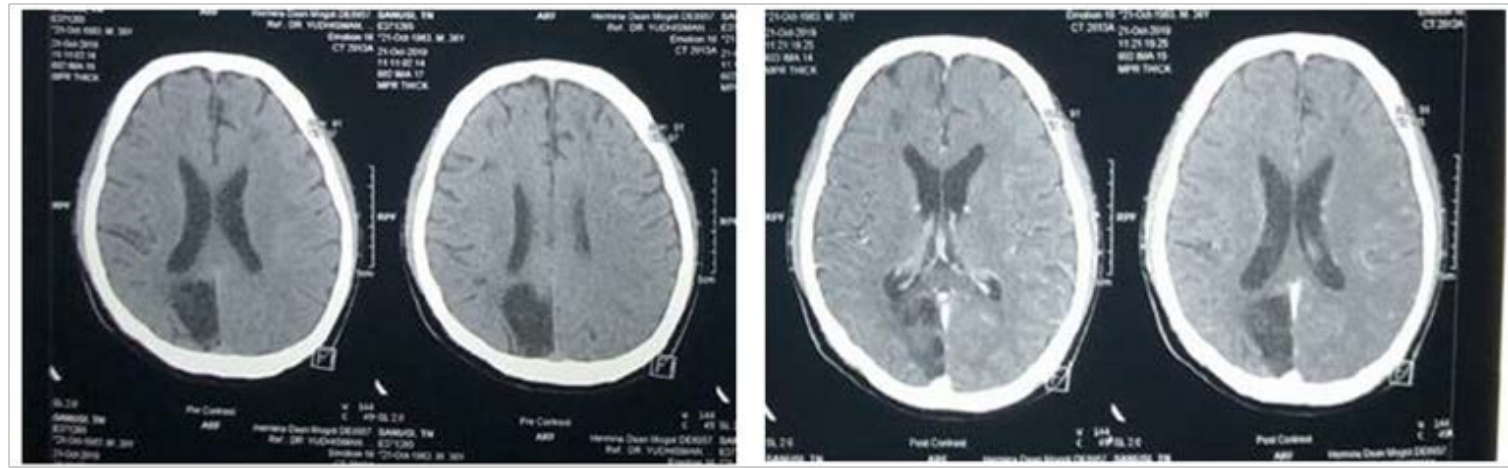

Interpretasi: Gambar Encephalomalacia cyst di parieto occipital kanan, chronic ischemic cerebral infark pada corona radiata kanan. Tidak tampak meningeal enhancement yang abnormal 


\section{PEMBAHASAN}

Meningitis

Tuberkulosis

(METB)

adalah infeksi selaput otak oleh Mycobacterium

Tuberculosis yang mengakibatkan kecacatan dan kematian pada lebih dari 30\% penderita METB. (1,5,11) Manifestasi klinis METB biasanya berupa demam, penurunan nafsu makan, nyeri kepala, mual, muntah. Pada pemeriksaan neurologis dapat ditemukan tanda rangsangan meningeal positif, gangguan kesadaran hingga koma. ${ }^{(9,12)}$ Pemeriksaan penunjang yang dapat dilakukan dengan pemeriksaan cairan serebrospinal, PCR dan CT Scan atau MRI kepala dengan kontras. ${ }^{(13)}$ Pada meningitis tuberkulosis, didapatkan adanya penyengatan kontras pada CT Scan kepala pada $90 \%$ kasus. ${ }^{(10)}$

Pada pasien ini dijumpai gejala klinis dan pemeriksaan neurologis yang mendukung diagnosis METB. Computerized Tomography Scan kepala dengan kontras didapatkan adanya penyengatan kontras di sisterna silvii bilateral dan sisterna basalis kronik iskemik serebral infark pada frontoparietal kanan. Sejalan dengan penelitian oleh Salma (2019) bahwa hidrosefalus merupakan komplikasi tersering METB, sedangkan 30\% komplikasi METB adalah stroke iskemik yang didapat melalui pemeriksaan imaging. ${ }^{(14)}$

Tujuan pengobatan antimikroba yang adekuat pada METB adalah untuk penyembuhan pasien, mencegah kematian karena TB aktif, mencegah kekambuhan $\mathrm{TB}$, mengurangi penularan TB dan mencegah penyebaran TB resisten obat. $(5,15)$ Durasi pemberian OAT bervariasi. Studi sebelumnya oleh Vreblevskaya et al menunjukkan terdapat perpanjangan terapi hingga 200 hari pada $51 \%$ pasien tuberkulosis termasuk meningitis tuberkulosis. ${ }^{(5)}$

Perpanjangan pengobatan tergantung pada frekuensi gejala yang lebih tinggi, reaksi obat yang merugikan, komorbiditas, cedera hati yang disebabkan OAT, waktu kultur yang lama dan variasi intra individu dalam konsentrasi obat. Pemberian kortikosteroid direkomendasikan 6 hingga 8 minggu. ${ }^{(7)}$ Pada kasus ini didapatkan gejala yang masih dirasakan berupa nyeri kepala hingga bulan ke 12 pengobatan, saat dilakukan pemeriksaan CT scan kepala masih didapatkan penyengatan kontras. Pengobatan dilanjutkan hingga bulan ke 18, setelah itu pasien tidak mengeluh nyeri kepala dengan hasil CT scan kepala membaik dan OAT dapat dihentikan.

\section{KESIMPULAN}

Pemberian OAT bervariasi pada setiap individu. Perpanjangan dan penghentian terapi dipertimbangan berdasarkan kondisi pasien dan dapat didukung dengan pemeriksaan penunjang seperti CT Scan kepala.

\section{UCAPAN TERIMA KASIH}

Terima kasih kepada RS Hermina Daan Mogot dan semua pihak yang membantu penulisan laporan kasus.

\section{KONFLIK KEPENTINGAN}

Tidak ada konflik internal antar penulis

\section{REFERENSI}

1. Gupta R, Talwar P, Pumanshi T, et al. Diagnostic accuracy of nucleic acid amplification based assays for tuberculous meningitis: A meta-analysis. J Infect 2018;77(4):302-13. doi: 10.1016/j. jinf.2018.04.017

2. Wilkinson RJ, Rohlwink U, Misra Uk, et al. Tuberculous Meningitis. Nat Rev Nutrol 2017;13(10);581-98. doi: 10.1038/ nrneurol.2017.120

3. Indah M. Tuberkulosis [Internet]. Infodatin. 2018:1-8. Available from: https://pusdatin.kemkes. go.id/resources/download/pusdatin/infodatin/ infodatin-tuberkulosis-2018.pdf

4. Chin JH. Tuberculous Meningitis; A neglectd tropical disease? Neurol Clin Pract 2019; 9(2):1524. doi:10.1212/CPJ.0000000000000606

5. Vrublevskaya NB, Daskapan A, Kosterink JGW, et al. Predictors of Prolonged TB Treatment in a Dutch Outpatien Setting. PLoS One 2016; 11(11): eO166030. doi: 10.1371/journal.pone.016603

6. Heemskerk AD, Bang ND, Mai NT, et al. Intensified Antituberculosis Therapy in Adult with Tuberculous Meningitis. N Engl J Med. 2016; 372(2):124-34. doi: 10.1056/NEJMoa1507062

7. Meisadona G, Soebroto AD, Estiasari R. Diagnosis dan tata laksana meningitis bakterialis. Cermin Dunia Kedokteran. 2015;42(1):15-9.

8. Knudsen GB, Solling M, Farre A, et al. Improved Outcome of Bacterial Meningitis Associated With Use Of Corticosteroid Treatment. Infect Dis (Lond) 2015;48(4):281-86. doi: 10.3109/23744235.2015.1109705

9. Garg RK, Malhotra HS, Jain A. Neuroimaging In Tubrculous Meningitis. Neurol India 2016;64;21927. doi: 10.4103/0028-3886.177608

10. Taheri MS, Karimi MA, Haghighatkhan $\mathrm{H}$, et al. Central Nervous System Tuberculosis : An Imaging-Focused Review Of A Reemerging Disease. Radiol Res Pract 2015;1-8. doi: 10.1155/2015/202806

11. Banuls AL, Sanou A, Van Ahn NT, et al. Mycobacterium tuberculosis: ecology and evolution of a human bacterium. J Med Microbiol 2015;64(11):1261-9. doi: 10.1099/jmm.0.000171 
12. Thwaites G, Chau TTH, Mai NTH, et al. Tuberculosis Meningitis. J Neurol Neurosurg Psychiatry 2000;68(3):289-99. doi: 10.1136/ jnnp.68.3.289

13. Saeed N, Islam A, Burki HB, et al. Clinical Manifestation of Extrapulmonary Tuberculous. Medical Channel. 2012;18(1);80-3

14. Haji S. Outcome of Tuberculous Meningitis in Adults. J Liaquat Uni Med Health Sci. 2019;18(01); 28-33. doi: 10.22442/jlumhs.191810597

15. Cresswell FV, Brak L, Athrton R, et al. Intensified Antibiotic Treatment of Tuberculosis Meningitis. Expert Rev Clin Pharmacol 2018;12(3):267-88. doi: $10.1080 / 17512433.2019 .1552831$ 